\title{
CONSUMER INNOVATIVENESS EFFECTS ON RETAIL EXTENSION EVALUATIONS
}

Merissa Chong, University of Queensland, Australia

Ravi Pappu, University of Queensland, Australia

Alastair Tombs, University of Queensland, Australia

\begin{abstract}
Retail firms are continually seeking ways to grow their business, sell more products, extend into new markets and so increase the equity of their brands. One successful growth strategy to achieve such objectives is brand extension. Despite considerable research in the area of brand extensions, there is surprisingly little research on how consumers view retail extensions. This study examines how consumer innovativeness affects their evaluations of two important components of the brand equity of retail extensions. The proposed conceptual model was tested for two global retailers that offered retail extensions of varying level of similarity to the parent retailer: McDonald's (who have extended their brand into McCafe) and KMart (who have extended their brand into KMart Tyre and Auto Service). Participants (n1=255, n2 = 250) were adult consumers who evaluated the store retailer brand and its retail extension on perceived quality, brand loyalty and reported their innovativeness. The results indicated that perceptions of quality mediated the impact of customer innovativeness on brand loyalty. These effects were stronger where the retailer-extension pair was similar rather than diverse.
\end{abstract}

References Available Upon Request 